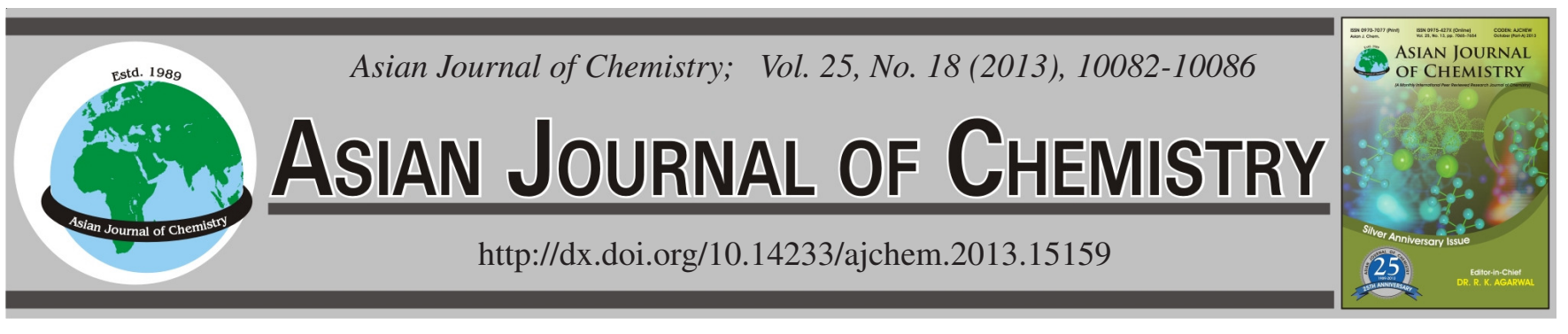

\title{
Effect of Heating on the Fatty Acid Composition and Oxidation Products of Flaxseed Oil
}

\author{
Zhen-Shan ZhANG ${ }^{1, *}$, Dong $\mathrm{LI}^{2}$ and Li-XIA ZhanG ${ }^{3}$
}

${ }^{1}$ College of Food Science and Technology, Henan University of Technology, No. 1, Lotus Flower Street, Zhengzhou 45001, P.R. China ${ }^{2}$ College of Engineering, China Agricultural University, 17 Qinghua Donglu, Beijing 100083, P.R. China

${ }^{3}$ Xinyang Agricultural Research Institute, Xinyang 464000, P.R. China

*Corresponding author: Tel: +86 13673996429; E-mail: zzsan010@gmail.com

\begin{abstract}
In this study, the oxidative changes of flaxseed oil at different heating temperatures were investigated. The oxidative degradation of flaxseed oil was evaluated by monitoring the peroxide value, fatty acid composition, content of conjugated dienes as absorbance at 232 $\mathrm{nm}$, content of conjugated trienes as absorbance at $270 \mathrm{~nm}$. Results showed that both of heating time and temperature had significant influence on the deterioration of flaxseed oil. The peroxide value, specific extinction coefficient at 232 and $270 \mathrm{~nm}$ were increased with the increasing of heating time at each temperature. The relative percentage of linolenic acid obviously decreased with increasing of heating time. However, the relative percentage of palmitic acid and oleic acid obviously increased with the increasing of heating time.
\end{abstract}

Key Words: Flaxseed oil, Oxidation, Heating, Fatty acid composition.

\section{INTRODUCTION}

Flaxseed, which is also called linseed, is an important oilseed in the world. It is mainly grown in Canada, America, China and India. Usually, flaxseed contains $40 \%$ oil, $30 \%$ dietary fiber, $20 \%$ protein, $4 \%$ ash and $6 \%$ moisture ${ }^{1}$. Flaxseed is known as the richest source of the n-3 fatty acid, $\alpha$-linolenic acid (ALA), which comprises $55 \%$ of the total fatty acids and this percentage is 5.5 times higher than that in the next-highest sources ${ }^{2}$. $\alpha$-Linolenic acid can be metabolized to eicosapentaenoic acid (EPA) and docosahexaenoic acid (DHA) in human intestine due to the action of some kinds of enzyme $^{3}$. It is well established, in human bodies, that an increase in the ingestion of long-chain polyunsaturated fatty acids (LC-PUFA), especially EPA and DHA, in diet can reduce the risk of diseases ${ }^{4}$. Previous studies have proven that flaxseed oil has positive effect on the minimization of many diseases such as hyperlipidemia ${ }^{5}$, colon tumor $^{6}$, mammary cancer $^{7}$ and atherosclerosis ${ }^{8}$.

However, $\alpha$-linolenic acid is sensitive to heat, oxygen and light. Compared with other edible oils, flaxseed oil is more prone to oxidation ${ }^{9}$. Oxidation is the main reason for the deterioration of edible oils and is the primary concern of manufacturers and consumers. Lukaszewicz et al., reported that even after cold extraction, to avoid rapid appearance of rancidity, flaxseed oil is often supplemented with vitamin E, stored in dark glass jars and may not be used for frying ${ }^{10}$.
Flaxseed oil is seldom used for frying or preparation of food when heat is involved, but in major flax-growing regions in China such as Gansu Province, flaxseed oil has been used as cooking oil and is favored by the local people over rapeseed or mustard oil ${ }^{11}$. Stir- frying is a popular cooking method of Chinese cooking. During stir-frying, the oil is heated as a thin film at a high temperature, which is reported to be a deteriorative process as oils oxidize rapidly due to the large surface to volume ratio. Several other factors could also interfere in oil oxidation process, such as, free fatty acid, oxygen exposure, water, light, trace metals and antioxidations. But the most important factor is still the temperature.

The objective of this study was to investigate the change of fatty acid composition and oxidation product of flaxseed oil which include peroxide value, conjugated dienes and trienes at different heating temperatures and time.

\section{EXPERIMENTAL}

Flaxseed (moisture content $6.2 \%$ ) was purchased from the market, which planted in Hebei province of China. The sample was cleaned by hand carefully to remove the foreign materials. Then, the cleaned flaxseed was preserved in hermetic bags at $-20^{\circ} \mathrm{C}$ until use.

Oil extraction: The cleaned flaxseed was ground into powder in a coffee grinder to pass a $1 \mathrm{~mm}$ screen. The ground flaxseeds were mixed with hexane at a ratio of 1:6 (w/v) in a flask. The mixture was agitated by a mechanical stirrer for $3 \mathrm{~h}$ 
at room temperature. The supernatant was then filtered through the filter paper under vacuum. The extraction procedure was repeated three times. The solutions were then collected and concentrated with a rotary evaporator to acquire the flaxseed oil. After centrifuging, the flaxseed oil obtained was further dried in a vacuum drying oven to remove the residual hexane.

Oil oxidation: Thirteen glass beakers of $50 \mathrm{~mL}$ (diameter $4 \mathrm{~cm}$ ) were prepared. Each beaker was injected $20 \mathrm{~mL}$ flaxseed oil. The beakers were put into oven and heated at set temperature for $48 \mathrm{~h}$ except blank. One beaker was taken from oven at intervals of $4 \mathrm{~h}$ and the oil was stored in brown bottle at -20 ${ }^{\circ} \mathrm{C}$ for subsequent analyses. The set temperatures were 35,75 , 105 and $135^{\circ} \mathrm{C}$, respectively.

Determination of peroxide value: The peroxide value of the flaxseed oil was determined according to the AOCS official methods (AOCS: Cd 8-33) ${ }^{12}$.

Determination of extinction coefficients: Extinction coefficients at 232 and $270 \mathrm{~nm}$ represent the ultraviolet absorbance of diene $\left(\mathrm{K}_{232}\right)$ and triene $\left(\mathrm{K}_{270}\right)$ conjugates of polyunsaturated fatty acids and they are also indication of oil oxidation. The extinction coefficients were determined according to the ISO-3656:2002 (E) method ${ }^{13}$.

Gas-chromatography analysis: Fatty acid composition was determined by gas chromatography after derivatization to fatty acid methyl esters (FAME). The preparation of FAME was performed according to the standard method (ISO 5509, $2000)^{14}$. FAME separation and identification were carried out on the gas chromatograph (Model CP-3800, Varian Inc, Walnut Creek, CA, USA) equipped with a flame ionization detector and capillary column HP-Innowax $(30 \mathrm{~m} \times 0.32 \mathrm{~mm} \times 0.25$ $\mu \mathrm{m})$. The amount of each sample injected was $1.0 \mu \mathrm{L}$. Nitrogen, at a constant flow $1.0 \mathrm{~mL} / \mathrm{min}$, was used as the carrier gas and a spilt/spiltless injector was used with a split ratio of 20:1. The injector temperature was $250^{\circ} \mathrm{C}$ and the detector temperature was $270^{\circ} \mathrm{C}$. The column temperature was programmed form $100-180^{\circ} \mathrm{C}$ at $20^{\circ} \mathrm{C} / \mathrm{min}$ and then to $230^{\circ} \mathrm{C}$ at $10^{\circ} \mathrm{C} / \mathrm{min}$ and held for $5 \mathrm{~min}$ at $230^{\circ} \mathrm{C}$. Fatty acid methyl esters were identified by comparison with the standard fatty acid methyl esters (Sigma, USA). Fatty acid methyl esters were quantified as percentages of the total methyl ester peak areas.

Statistical analysis: Each reported value is the mean of determinations for triplicate sample. The statistical analysis of the data, correlation and regression was carried out with Microsoft ${ }^{\circledR}$ Office Excel 2003 software.

\section{RESULTS AND DISCUSSION}

Change of peroxide value: The chemical mechanism of thermal oxidation is principally the same as the autoxidation mechanism, but the thermal oxidation rate is faster than the autoxidation rate ${ }^{15}$. Autoxidation is the most common process leading to oxidative deterioration and is defined as the spontaneous reaction of atmosphere oxygen with lipids ${ }^{16}$. Usually, autoxidation was explained by free radical chain reaction. The reaction process is divided into three phases: initiation, propagation and termination. A simplified scheme of autoxidation mechanism is given below ${ }^{17}$ :

Initiation:

$$
\mathrm{RH} \stackrel{\text { Initiator }}{\longrightarrow} \mathrm{R}^{\bullet}+\mathrm{H}^{\bullet}
$$

Propagation:

$$
\begin{gathered}
\mathrm{R}^{\bullet}+\mathrm{O}_{2} \longrightarrow \mathrm{ROO} \\
\mathrm{ROO}^{\bullet}+\mathrm{RH} \longrightarrow \mathrm{ROOH}+\mathrm{R}^{\bullet}
\end{gathered}
$$

Termination:

$$
\left.\begin{array}{l}
\mathrm{R}^{\bullet}+\mathrm{R}^{\bullet} \longrightarrow \\
\mathrm{R}^{\bullet}+\mathrm{ROO}^{\bullet} \longrightarrow \\
\mathrm{ROO}^{\bullet}+\mathrm{ROO}^{\bullet} \longrightarrow
\end{array}\right\} \text { Nonradical products }
$$

Edible oil was oxidized in atmosphere to generate primary oxidation product, namely, hydroperoxide. Decomposition and polymerization of hydroperoxide leaded to the formation of volatile and nonvolatile secondary oxidation products. Volatile products were responsible for unique odor or "rancid odor" of edible oil. Nonvolatile products mainly included aldehydes, ketones, alcohols, hydrocarbons, epoxy compounds ${ }^{18}$. The general process of lipid autoxidation was shown in Fig. 1. Autoxidation reaction of lipid is a dynamic process. Generation of hydroperoxide is always accompanied by its decomposition and polymerization.

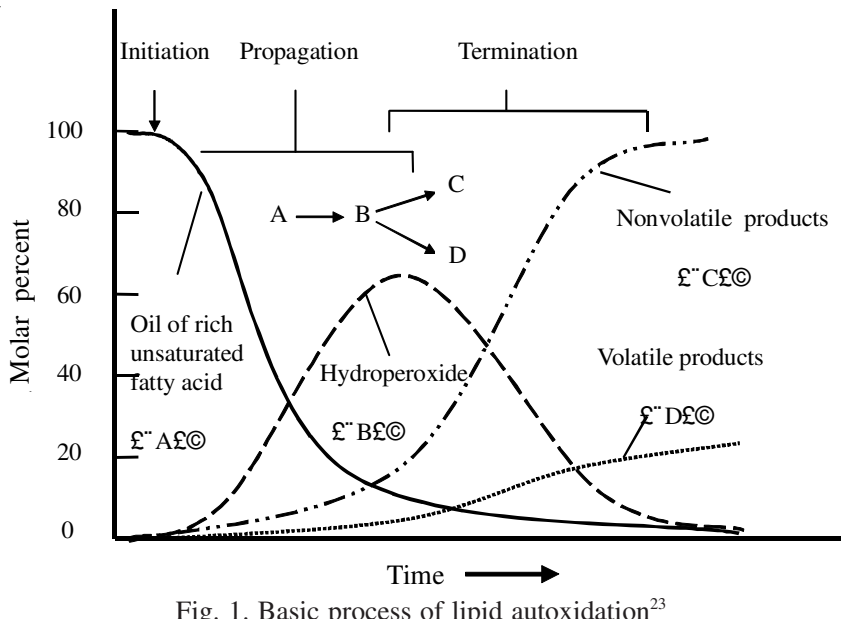

The effect of heating on the peroxide value was shown in Fig. 2. Peroxide value of flaxseed oil increased with increasing of heating time at 35,75 and $105^{\circ} \mathrm{C}$, respectively. There was a positive and strong linear relationship between peroxide value and heating time (Table-1). A correlation greater than 0.8 is generally described as strong, whereas a correlation less than 0.5 is generally described as weak. Moreover, at $35^{\circ} \mathrm{C}$, the growth of peroxide value was slow, almost at a standstill when heating time less than $36 \mathrm{~h}$. Over $36 \mathrm{~h}$, peroxide value significantly increased with increasing of heating time. This phenomenon can be explained by the oxidation induction period $^{19}$.

At 75 and $105^{\circ} \mathrm{C}$, the values of peroxide value were almost same at different heating time. This may be due to the poor thermal stability of primary product (hydroperoxide), which was prone to decomposition at high temperatures. Usually, the higher the heating temperature, the faster the decomposition of hydroperoxide ${ }^{20}$. The same peroxide value at different heating temperatures indicated that there was no linear relationship between the peroxide value and temperature. Flax-seed oil 
$35^{\circ} \mathrm{C}$

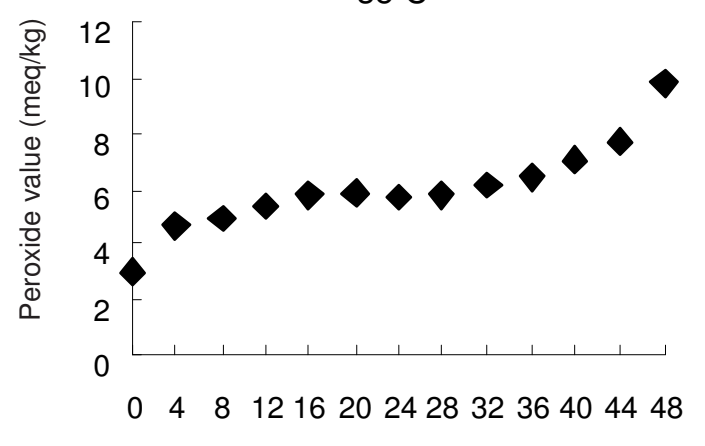

Heating time $(h)$
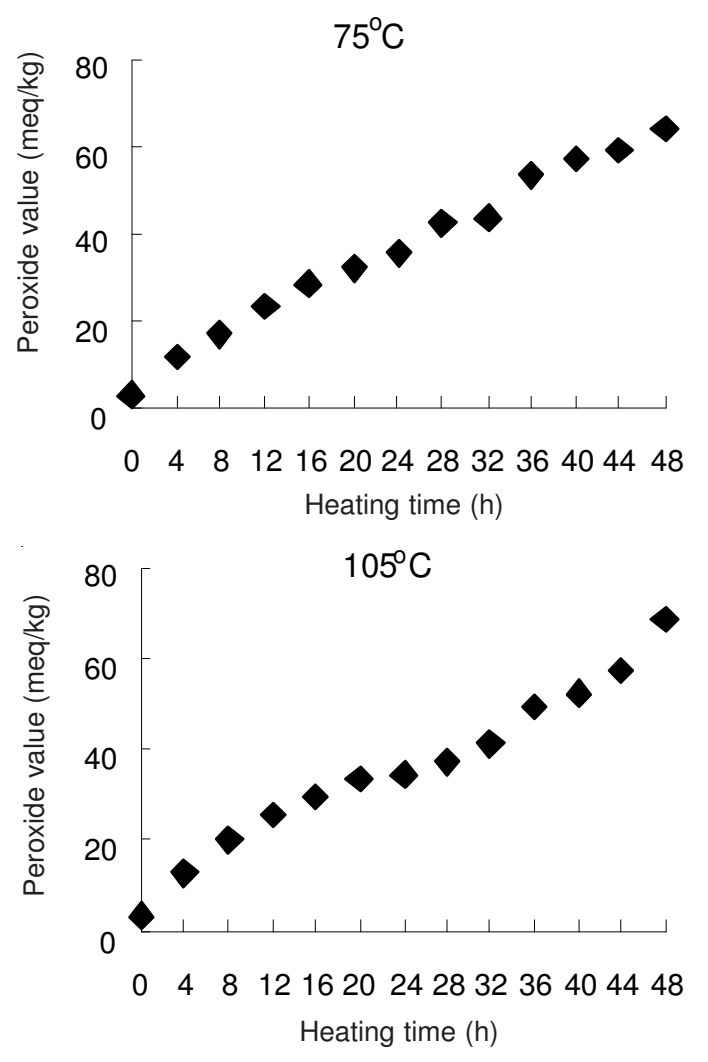

Fig. 2. Effect of heating on the peroxide value of flaxseed oil

\begin{tabular}{ccc}
\multicolumn{4}{c}{ TABLE-1 } \\
\multicolumn{3}{c}{ REGRESSION EQUATION BETWEEN PEROXIDE } \\
\multicolumn{3}{c}{ VALUE OF FLAXSEED OIL AND HEATING TIME } \\
\hline $\begin{array}{ccc}\text { Heating temp. } \\
\left({ }^{\circ} \mathrm{C}\right)\end{array}$ & $\begin{array}{c}\text { Regression } \\
\text { equation }\end{array}$ & $\begin{array}{c}\text { Correlation } \\
\text { coefficient }\end{array}$ \\
\hline 35 & $\mathrm{Y}=0.0928 \mathrm{x}+3.7917$ & $\mathrm{R}=0.9042$ \\
75 & $\mathrm{Y}=1.2256 \mathrm{x}+6.6353$ & $\mathrm{R}=0.9954$ \\
105 & $\mathrm{Y}=1.1577 \mathrm{x}+7.9407$ & $\mathrm{R}=0.9857$ \\
135 & $\mathrm{Y}=-0.0474 \mathrm{x}^{2}+2.6590 \mathrm{x}+0.7595$ & $\mathrm{R}=0.9637$ \\
\hline
\end{tabular}

oil may follow different autoxidation mechanism at different oxidation temperatures ${ }^{21}$. Similar result was also obtained in the study of unpurified salmon oil by Huang et al..$^{22}$.

A quadratic linear relationship was shown between peroxide values and heating time at heating temperature of $135{ }^{\circ} \mathrm{C}$ (Table-1). This trend was similar with that of hydroperoxide depicted in Fig. 1. It indicated that flaxseed oil can be rapidly oxidized to hydroperoxide and hydroperoxide was unstable at high temperature. At this temperature, peroxide value as an indicator of oxidative degradation is no longer appropriate for flaxseed oil. Similar result was also obtained at $130^{\circ} \mathrm{C}$ by Hess and Hare ${ }^{23}$.

Change of extinction coefficient at 232 and $270 \mathrm{~nm}$ : The change of $K_{232}$ was shown in Fig. 3. It can be seen that $\mathrm{K}_{232}$ increased with the increase of heating time at different temperatures. This indicated that heating time had a significant influence on the degree of oxidation of flaxseed oil. It can also be found that heating temperature had a great impact on the $\mathrm{K}_{232}$. With the increase of heating temperature, $\mathrm{K}_{232}$ of flaxseed oil increased significantly, especially when heating temperature over $105^{\circ} \mathrm{C}$. At heating temperature of $35^{\circ} \mathrm{C}$, $\mathrm{K}_{232}$ increased from initial 2.25 to final 2.59 after heating for $48 \mathrm{~h}$, only increased by 0.34 . However, at heating temperature of $135^{\circ} \mathrm{C}, \mathrm{K}_{232}$ increased by 37.51 after heating for $32 \mathrm{~h}$.

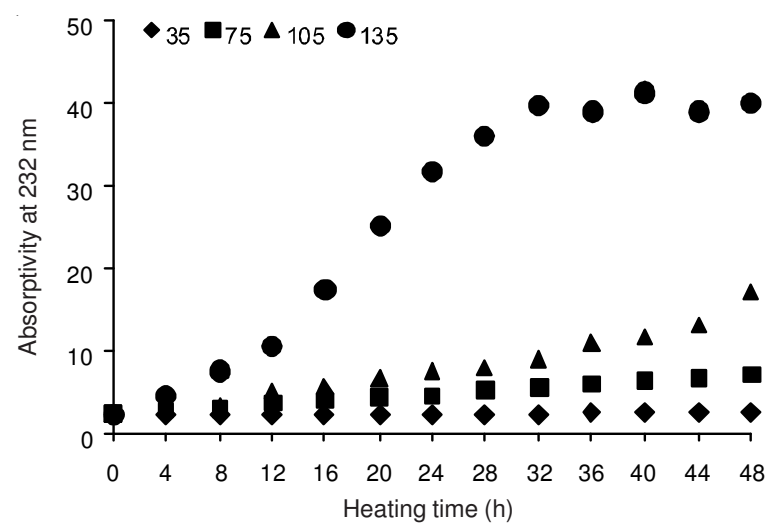

Fig. 3. Effect of heating time on the absorptivity at $232 \mathrm{~nm}$ of flaxseed oil

Generally, the variation of absorptivity at $270 \mathrm{~nm}\left(\mathrm{~K}_{270}\right)$ was attributed to the formation of conjugated trienes as well as unsaturated ketones and aldehydes ${ }^{24}$. The change of $\mathrm{K}_{270}$ at different heating temperatures was shown in Fig. 4. $K_{270}$ increased with the increase of heating time. Similar with the change of $\mathrm{K}_{232}$, heating temperature also had a great influence on $\mathrm{K}_{270}$ of flaxseed oil. At heating temperature of $35^{\circ} \mathrm{C}, \mathrm{K}_{270}$ increased from initial 0.25 to final 0.30 in $48 \mathrm{~h}$, only increased by 0.05 . But, at heating temperature of $135^{\circ} \mathrm{C}, \mathrm{K}_{270}$ increased by 9.90 after heating for $32 \mathrm{~h}$. At $135^{\circ} \mathrm{C}$, both of $\mathrm{K}_{232}$ and $\mathrm{K}_{270}$ tended to increase initially and then plateau off during later stage of heating. This has been related to the establishment of equilibrium between the rate of formation of conjugated dienes or trienes and the rate of formation of polymers formed by a Diels Alder reaction ${ }^{15}$.

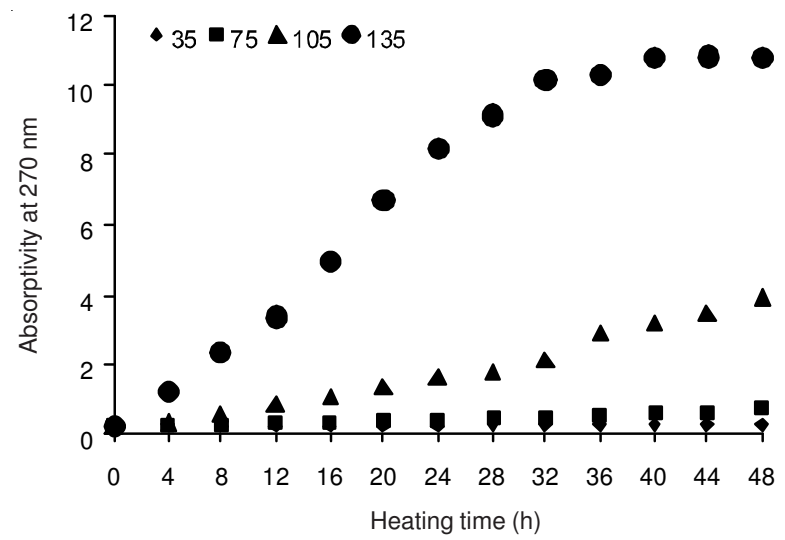

Fig. 4. Effect of heating time on the absorptivity at $270 \mathrm{~nm}$ of flaxseed oil 
TABLE-2

REGRESSION EQUATION BETWEEN EXTINCTION COEFFICIENTS OF FLAXSEED OIL AND HEATING TIME

\begin{tabular}{cccc}
\hline \multirow{2}{*}{ Heating temperature $\left({ }^{\circ} \mathrm{C}\right)$} & \multicolumn{2}{c}{$232 \mathrm{~nm}$} & \multicolumn{2}{c}{$270 \mathrm{~nm}$} \\
\cline { 2 - 4 } & Regression equation & $\mathrm{R}$ & Regression equation \\
\hline 35 & $\mathrm{Y}=0.0060 \mathrm{x}+2.2222$ & 0.9182 & $\mathrm{Y}=0.0002 \mathrm{x}+0.2498$ \\
75 & $\mathrm{Y}=0.1006 \mathrm{x}+2.3148$ & 0.9982 & $\mathrm{Y}=0.0091 \mathrm{x}+0.2294$ \\
105 & $\mathrm{Y}=0.2731 \mathrm{x}+1.3707$ & 0.9760 & $\mathrm{Y}=0.0786 \mathrm{x}-0.0831$ \\
135 & $\mathrm{Y}=0.9260 \mathrm{x}+3.4859$ & 0.9508 & $\mathrm{Y}=0.2452 \mathrm{x}+0.9658$ \\
\hline
\end{tabular}

Compare Fig. 3 with Fig. 4, it can be found that $\mathrm{K}_{270}$ and $\mathrm{K}_{232}$ had a similar change trend at different heating temperatures. However, the values of $\mathrm{K}_{232}$ were larger than that of $\mathrm{K}_{270}$. The similar result was obtained by Ramadan et al., who stored black cumin, coriander and niger crude seed oils at $60^{\circ} \mathrm{C}$ for $21 \mathrm{~d}^{25}$. The same result was also obtained in virgin olive oil by Kyriakidis and Dourou ${ }^{26}$. However, compared with their studies, the UV absorbance of flaxseed oil showed a larger value and greater change in a shorter time, this may be due to the flaxseed oil contains more unsaturated fatty acid, especially, linolenic acid (above $50 \%$ ).

Oil oxidation not only was determined by the heating temperature and time, but also depended on the contact area between the oil and air. Choo et al., spread flaxseed oil as a thin-film in a frying pan and heated at approximately $150^{\circ} \mathrm{C}$. It was found that $\mathrm{K}_{232}$ and $\mathrm{K}_{270}$ increased from initial 2.3 and 0.3 to 34.5 and 12.8 , respectively, after heating only for $6 \mathrm{~min}^{8}$.

The regression equation between extinction coefficient at 232 and $270 \mathrm{~nm}$ and heating time at different temperatures were shown in Table-2. It can be seen that there is a positive correlation and strong linear relationship between $\mathrm{K}_{232}, \mathrm{~K}_{270}$ and heating time at each temperature.

Change of fatty acid composition: The change of fatty acid composition was shown in Fig. 5. It can be obtained that oxidation of flaxseed oil caused a significant increase of the relative content of palmitic acid and oleic acid $(p<0.05)$. Meanwhile, a significant reduction was shown in the relative content of linolenic acid $(p<0.05)$. The increase of relative content of stearic acid and linoleic acid were not significant at lower temperature $\left(35\right.$ and $75^{\circ} \mathrm{C}$ ), but it was significant at higher temperature $\left(105\right.$ and $\left.135^{\circ} \mathrm{C}\right)$. Similar results were obtained by Choo et al., who heated flaxseed oil at $150^{\circ} \mathrm{C}$ as a thin film in a frying pan for 3 and $6 \mathrm{~min}$, respectively ${ }^{8}$. It is noteworthy that the relative content of linoleic acid markedly decreased in other studies ${ }^{27}$. This maybe due to linolenic acid is more susceptible to oxidation than linoleic acid and the oils were lack in linolenic acid for their studies.

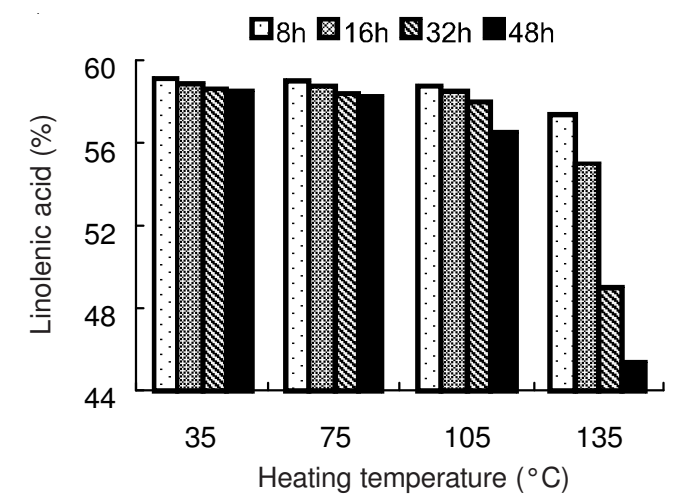

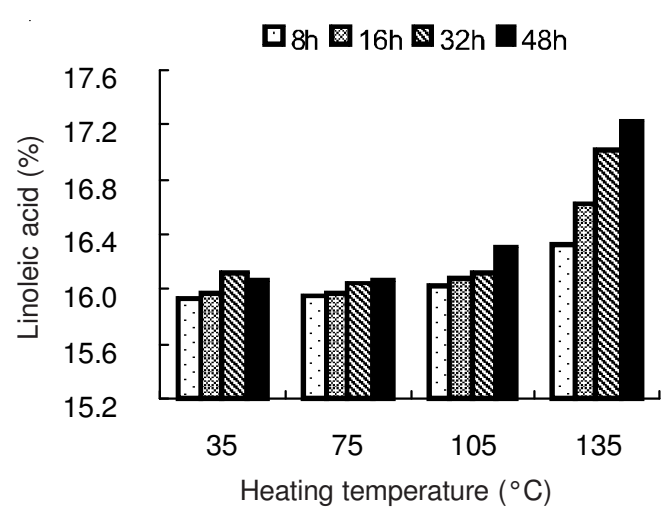
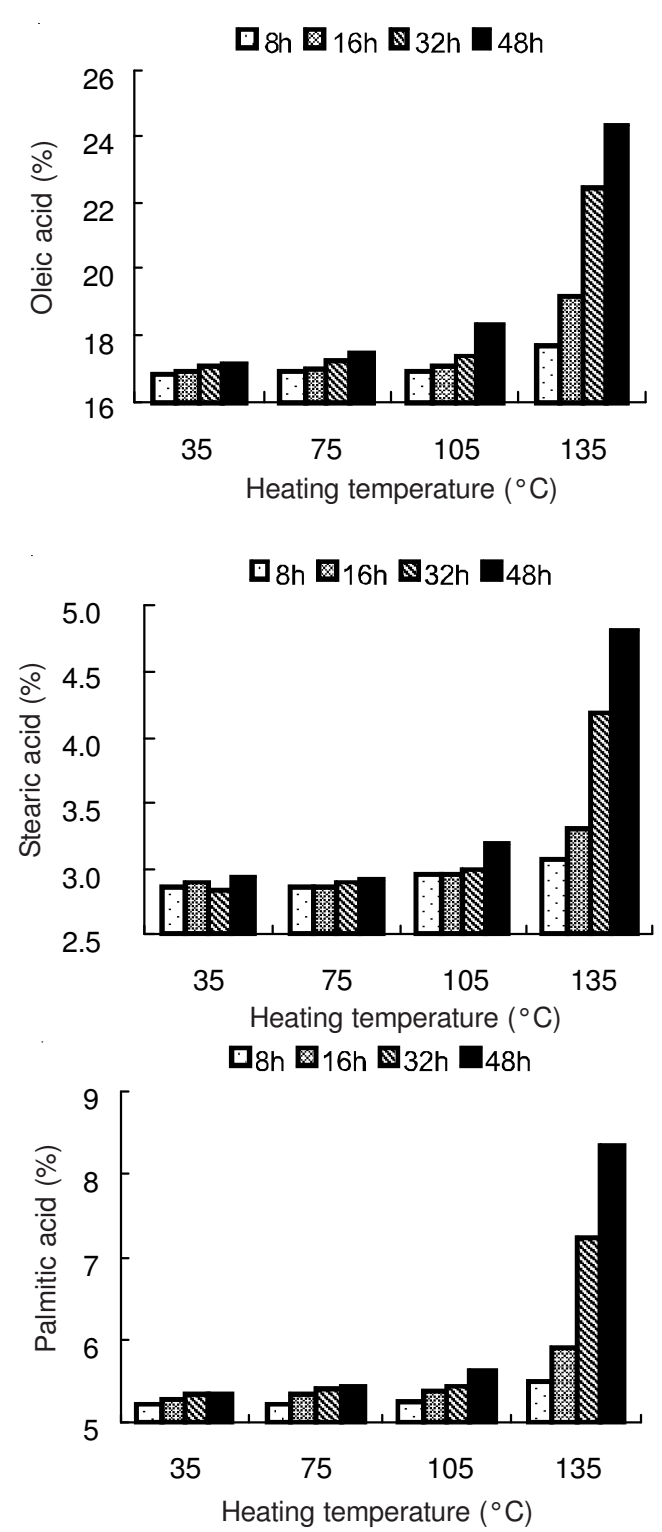

Fig. 5. Effects of heating on the fatty acid composition of flaxseed oil 
It was also found that heating temperature had an important influence on the fatty acid composition. When heating temperature lower than $105^{\circ} \mathrm{C}$, the relative content of each fatty acid have undergone a change, but the amplitude of change was small. At $105^{\circ} \mathrm{C}$ for $48 \mathrm{~h}$, compared with the initial content, the relative percentage of linolenic acid decreased by $2.69 \%$, linoleic acid, oleic acid, stearic acid and palmitic acid increased by $0.34,1.50,0.30$ and $0.53 \%$, respectively. However, at $135^{\circ} \mathrm{C}$ for $16 \mathrm{~h}$, compared with the initial content, the relative percentage of linolenic acid decreased by $4.23 \%$, linoleic acid, oleic acid, stearic acid and palmitic acid increased by $0.65,2.34,0.43$ and $0.81 \%$, respectively. Thus, high temperature should be avoided in the process of flaxseed oil extraction, refining, storage and use.

The regression equation between the major fatty acids and heating time were shown in Table-3. It can be seen that regression equation was the worst for stearic acid. At $35^{\circ} \mathrm{C}$, the correlation coefficient $(\mathrm{R})$ was only 0.3050 . Contrary to the stearic acid, correlation coefficient of oleic acid and linolenic acid were always greater than 0.95 . When heating temperature above $105^{\circ} \mathrm{C}$, a very strong linear correlation were obtained between all five fatty acids and heating time.

\begin{tabular}{|c|c|c|c|}
\hline \multicolumn{4}{|c|}{$\begin{array}{c}\text { TABLE-3 } \\
\text { REGRESSION EQUATION BETWEEN RELATIVE } \\
\text { CONTENT OF FATTY ACIDS AND OXIDATION TIME }\end{array}$} \\
\hline $\begin{array}{l}\text { Heating } \\
\text { temp. }\left({ }^{\circ} \mathrm{C}\right)\end{array}$ & $\begin{array}{l}\text { Fatty } \\
\text { acid }\end{array}$ & $\begin{array}{c}\text { Regression } \\
\text { equation }\end{array}$ & $\begin{array}{l}\text { Correlation } \\
\text { coefficient }\end{array}$ \\
\hline \multirow{5}{*}{35} & Palmitic (C16:0) & $Y=0.004 x+5.176$ & $\mathrm{R}=0.8301$ \\
\hline & Stearic (C18:0) & $Y=0.000 x+2.866$ & $R=0.3050$ \\
\hline & Oleic (C18:1) & $Y=0.008 x+16.77$ & $\mathrm{R}=0.9920$ \\
\hline & Linoleic (C18:2) & $Y=0.003 x+15.95$ & $\mathrm{R}=0.8037$ \\
\hline & Linolenic (C18:3) & $Y=-0.016 x+59.21$ & $\mathrm{R}=0.9839$ \\
\hline \multirow{5}{*}{75} & Palmitic (C16:0) & $Y=0.006 x+5.167$ & $\mathrm{R}=0.9055$ \\
\hline & Stearic (C18:0) & $Y=0.000 x+2.874$ & $R=0.7537$ \\
\hline & Oleic (C18:1) & $Y=0.013 x+16.77$ & $\mathrm{R}=0.9930$ \\
\hline & Linoleic (C18:2) & $Y=0.002 x+15.94$ & $\mathrm{R}=0.9434$ \\
\hline & Linolenic (C18:3) & $Y=-0.023 x+59.23$ & $\mathrm{R}=0.9950$ \\
\hline \multirow{5}{*}{105} & Palmitic (C16:0) & $Y=0.009 x+5.156$ & $R=0.9808$ \\
\hline & Stearic (C18:0) & $Y=0.005 x+2.867$ & $\mathrm{R}=0.9386$ \\
\hline & Oleic (C18:1) & $Y=0.029 x+16.63$ & $\mathrm{R}=0.9529$ \\
\hline & Linoleic (C18:2) & $Y=0.006 x+15.96$ & $\mathrm{R}=0.9492$ \\
\hline & Linolenic (C18:3) & $Y=-0.051 x+59.37$ & $\mathrm{R}=0.9664$ \\
\hline \multirow{5}{*}{135} & Palmitic (C16:0) & $Y=0.069 x+4.959$ & $\mathrm{R}=0.9955$ \\
\hline & Stearic (C18:0) & $Y=0.042 x+2.768$ & $\mathrm{R}=0.9930$ \\
\hline & Oleic (C18:1) & $Y=0.165 x+16.69$ & $\mathrm{R}=0.9925$ \\
\hline & Linoleic (C18:2) & $Y=0.025 x+16.10$ & $\mathrm{R}=0.9767$ \\
\hline & Linolenic (C18:3) & $Y=-0.303 x+59.46$ & $\mathrm{R}=0.9960$ \\
\hline
\end{tabular}

\section{Conclusion}

The peroxide value, extinction coefficient at 232 and $270 \mathrm{~nm}$ were gradually increased with the increase of time when flaxseed oil was heated, especially when the heating temperature was higher than $75^{\circ} \mathrm{C}$. Oxidation will change the basic composition of fatty acids of flaxseed oil. The relative content of linolenic acid reduced significantly as the deepening of oxidation. Meanwhile, the relative contents of linoleic acid, oleic acid, stearic acid, palmitic acid increased with the deepening of oxidation.

\section{ACKNOWLEDGEMENTS}

Research support was provided by National Natural Science Foundation of China (No. 31101367), High-level Talent Fund of Henan University of Technology (2011BS012).

\section{REFERENCES}

1. Z.S. Zhang, L.J. Wang, D. Li, S.S. Jiao, X.D. Chen and Z.H. Mao, Sep. Purif. Technol., 62, 192 (2008).

2. L.T. Bloedon and P.O. Szapary, Nutr. Rev., 62, 18 (2004).

3. J. Chen, P.M. Stavro and L.U. Thompson, Nutr. Cancer, 43, 187 (2002).

4. J.V. Visentainer, N.E. Souza, M. Makoto, C. Hayashi and M.R.B. Franco, Food Chem., 90, 557 (2005).

5. K. Vijaimohan, M. Jainu, K.E. Sabitha, S. Subramaniyam, C. Anandhan and C.S. Shyamala Devi, Life Sci., 79, 448 (2006).

6. C. Dwivedi, K. Natarajan and D.P. Matthees, Nutr. Cancer, 51, 52 (2005).

7. L. Wang, J. Chen and L.U. Thompson, Int. J. Cancer, 116, 793 (2005).

8. K. Prasad, Atherosclerosis, 132, 69 (1997).

9. J.M. Nzikou, L. Matos, J.E. Moussounga, C.B. Ndangui, N.P. PambouTobi and E.M. Bandzouzi, Res. J. Appl. Sci., 4, 94 (2009).

10. M. Lukaszewicz, J. Szopa and A. Krasowska, Food Chem., 88, 225 (2004).

11. W.S. Choo, E.J. Birch and J.P. Dufour, J. Am. Oil Chem. Soc., 84, 735 (2007).

12. Association of Official Analytical Chemists, Official Methods and Recommended Practices of the American Oil Chemists' Society, AOCS: Illinois, USA, edn. 5 (1997).

13. ISO, 3656: Animal and Vegetable Fats and Oils-Determination of Ultraviolet Absorbance Expressed as Specific UV extinction, ISO: Geneva, edn. 3 (2002).

14. ISO, 5509: Animal and Vegetable Fats and Oils-Preparation of Methyl Esters of Fatty Acids, ISO: Geneva, edn. 2 (2000).

15. E.M. Marinova, K.A. Seizova, I.R. Totseva, S.S. Panayotova, I.N. Marekov and S.M. Momchilova, Bulgarian Chem. Commun., 44, 57 (2012).

16. J. Lee, Y. Lee and E. Choe, Eur. Food Res. Technol., 226, 239 (2007).

17. N.V. Yanishlieva and E.M. Marinova, Eur. J. Lipid Sci. Technol., 103, 752 (2001).

18. E.N. Frankel, J. Am. Oil Chem. Soc., 61, 1908 (1984).

19. J. Velasco, M.L. Andersen and L.H. Skibsted, Food Chem., 85, 623 (2004).

20. I. Aidos, S. Lourenco, A. Van der Padt, J.B. Luten and R.M. Boom, J. Food Sci., 67, 3314 (2002).

21. Ö.K. Güler, F.S. Güner and A.T. Erciyes, Prog. Org. Coat., 51, 365 (2004).

22. J.Q. Huang and S. Sathivel, J. Food Eng., 89, 105 (2008).

23. P.S. Hess and G.A. O'Hare, Ind. Eng. Chem., 42, 1424 (1950).

24. A.C. de Camargo, T.M.F.S. Vieira, M.A.B. Regitano-D'Arce, S.M. de Alencar, M.A. Calori-Domingues and S.G. Canniatti-Brazaca, Int. J. Mol. Sci., 13, 2827 (2012).

25. M.F. Ramadan and J.-T. Morsel, Eur. J. Lipid Sci. Technol., 106, 35 (2004).

26. N.B. Kyriakidis and E. Dourou, J. Food Lipids, 9, 47 (2002).

27. A.R.M. Suleiman, A. El-Makhzangy and M.F. Ramadan, J. Food Lipids, 13, 259 (2006). 